\title{
Status of Wheat Rust Diseases in Hadiya Zone, Ethiopia
}

\author{
Alemayehu Ayele ${ }^{*} \quad$ Yilma Dessalegn* Selamawit Tesfaye \\ Wachemo University, Collage of Agricultural Science, Department of Plant Science, Ethiopia
}

\begin{abstract}
Hadiya Zone is one of the major wheat producing areas in Ethiopia and it is recognized as one of the wheat belts in the country. But wheat production is threatened by abiotic and biotic constraints. Among the biotic, wheat rust (stem rust, yellow rust and stripe rust) is one of the major limitations of wheat production. Even though, Hadiya zone is known in wheat production, there is no detailed information regarding the distribution, incidence and severity of wheat rust. Therefore, this study was conducted with the following objectives: to determine distribution, incidence and severity of wheat rust and to assess the reaction of varieties against wheat rust. The survey was conducted in 2017main cropping season from mid September to mid October in three districts of Hadiya zone (Misha, Lemo and Duna). A total of 72 fields were surveyed at every 5 to $10 \mathrm{~km}$ using vehicle odometer along the main and accessible road sides. The plant samples with in a selected field were taken in X-fashion using $0.5 \mathrm{~m} \mathrm{X}$ $0.5 \mathrm{~m}\left(0.25 \mathrm{~m}^{2}\right)$ quadrats. Rusts incidence and severity were recorded from six quadrats along the two diagonals of the $\mathrm{X}$ axis in the field and used to calculate average values. The result indicated that, stem, yellow and leaf rust mean incidence value $67.18 \%, 4.44 \%$ and $4.4 \%$ were recorded in the surveyed areas, respectively and mean severity value of $9 \%, 3 \%$ and $2.3 \%$ in the same order. Reaction of wheat varieties to stem rust ranges from $5.5 \%$ - $16 \%$. The lowest severity of stem rust was recorded on variety Digalu $(5.5 \%)$ where as the highest was from local variety $(16 \%)$. In general, disease severity was classified under low class. The survey work showed that if susceptible improved and local cultivars continue to grow as mono-cropping system (due to strategy of cluster farming) serious wheat rust epidemics may occur in the zones and may cause high economic loss. Therefore, it is advised to device other farming system instead of cluster farming and replacing of susceptible varieties with new resistant varieties. Moreover, the supply of fungicides in the survey area was a problem that must be solved by the concerned body.
\end{abstract}

DOI: $10.7176 / \mathrm{JBAH} / 10-5-05$

Publication date:March $31^{\text {st }} 2020$

\section{INTRODUCTION}

Wheat is an important cereal crop in Ethiopia that is widely cultivated in a wide range of altitude which falls between 1900-2700 m.a.s.l. (Hailu, 1991). It is the main staple food for about 36\% of the Ethiopian population (CSA, 2004; CIMMYT, 2005). The area under wheat production is estimated to be about 1.66 million hectares, which makes the country the largest wheat producer in Sub-Saharan Africa (Hailu, 1991; CSA, 2015). Wheat ranks fourth in area coverage and total production after teff, maize and sorgum (CSA, 2015).

The national average yield of wheat in Ethiopia is about 25.43 quintals/ha (CSA, 2015). This is by far below the world's average which is about 32.6quintals /ha (USDA, 2015).Hadiya Zone is one of the major wheat producing areas in Ethiopia and it is recognized as one of the wheat belts in the country. Wheat production in Hadiya Zone was the leading in area coverage as well as in production as compared to other crops in the cropping season of 2014/2015 (CSA, 2015). About 13,352 hectares of land were devoted to wheat production by subsistence farmers in Hadiya zone and the average production per hectare was 26.43 quintal which is far below the average African and world yield productivity (USDA, 2015; CSA, 2015). Multifaceted biotic and abiotic factors are responsible for the low yield of the crop. Cultivation of unimproved low yielding varieties, insufficient and erratic rainfall, poor agronomic practices, diseases and insect pests are among the most important constraints to wheat production in Ethiopia (Hailu, 1991; Dereje and Yaynu, 2000). Among these factors, diseases play a significant role in yield reduction worldwide.

Wheat is susceptible to many diseases including the highly destructive ones like rusts (Puccinia spp.), Septorialeaf blotches (Septoriatritici), Fusariumhead blight (Fusariumgraminearum), tan spot (Pyrenophoratriticirepentis), smut (Ustilagotritici) and powedery mildew (Erysiphegraminisf.sp.tritici). Of these, fungal diseases like rusts (stem, stripe and leaf rust), Fusariumhead blight (FHB), Septoria blotch, Helminthosporium spp., and tan spot are the dominant ones that were reported over time (CIMMYT, 2005). Among these cereal rusts are the most destructive diseases of wheat worldwide,inspite of great progress made in their control in many countries and considered the major diseases of wheat since no other wheat disease could result in greater loss over large area in a given year ((Saari and Prescot, 1985; Haldoreet al., 1982; Stakmanet al., 1962).The persistence of rust as a major disease in wheat can be attributed to specific characteristics of the rust fungi. Its characteristics include a capacity to change genetically, by producing new races with increased aggressiveness on resistant wheat cultivars and to produce a large number of spores which can be winddisseminated over long distances and infect wheat under favorable environmental conditions. 
Stem rust caused by the fungus Puccinia graminisf. sp. Tritici Eriks. and E. Henn, has been the most devastating of all wheat diseases under favorable conditions. This disease is also known as black rust of wheat due to the abundant production of shiny black teliospores that form at the end of the season or with unfavorable conditions (Singh et al., 2002). The wheat stripe (yellow) rust caused by PucciniastriiformisWest. f. sp. Triticiand leaf rust (P. triticinaEriks.) are major constraints to increased yieldglobally (Knott, 1989; Das et al., 1992). Stem rust and leaf rust are favored by humid condition and relatively warm temperature while stripe rust is important under cool and moist environmental conditions (Knott, 1989). Rust mainly attacks wheat but can also infect many other small cereals including barley, oat and rye and forage grasses (Roelfset al., 1987).

Ethiopia is one of the hot spot areas for the development of the present wheat rust complex (Leppik, 1970). The occurrence of cereal rusts in Ethiopia has been recognized as early as the 1930s (Mengistuet al., 1991). Dagnachew (1967) reported cereal rusts to be the most important diseases of wheat. Rusts can cause up to 60 percent of yield loss for leaf or stripe (yellow) rust and 100 percent loss for stem rust depending on the susceptibility of the variety and environmental conditions (Parket al., 2007). In Hadiya zone, information on the effect of rust on wheat yield is scanty. Before designing any plant disease management or after application of management activities, it is important to assess diseases to quantify the distribution and severity of the disease in the area. In this regard, disease surveying is basic to all effective control and research programs.

Despite the frequent occurrence of severe epidemics of the rust disease and wheat production in Hadiya zone is the leading in area coverage and production, there is no detailed information with regard to the development and temporal dynamics of wheat rust and their relative importance on yield loss rather a 'fire extinguishing' style of crop protection which try to utilize control strategies where disease outbreak occurred. So, it was rationale to assess diseases in order to make decision on selection or designing of sustainable control or management strategies or to assess the effectiveness of the management activities applied in a given area. Therefore, disease monitoring and surveillance are of paramount significant for sustainable wheat production and tackle food insecurity.

Hence, this research was conducted with following objectives:

To assess the distribution, incidence and severity of wheat rust

\section{Experimental Procedure}

Field surveys were carried out in conducted in Hadiya Zone from mid-September to mid-October 2017 during which stem rust was expected to reach its maximum severity level (Serbessa, 2003). Wheat rust survey was conducted in three districts of Hadiya zone (Misha, Lemo and Duna) during main cropping season of 2017. These districts were selected purposively based on their potential in wheat production in the Hadiya zone and these district had mid highland (1500-2300 m.a.s.l) and highland (2301-3000 m.a.s.l) agro-ecologies. A total of 12 PA's was selected from the three districts and this was allocated by proportional based on the number of PA's in each districts. PAs was selected from each district using purposive sampling procedures (with high wheat coverage) and from each PA's6 wheat fields were assessed at every 5 to $10 \mathrm{~km}$ using vehicle odometer along the main and accessible roadsides.

The plant samples were taken in X-fashion using $0.5 \mathrm{mX} 0.5 \mathrm{~m}\left(0.25 \mathrm{~m}^{2}\right)$ quadrats. Rusts incidence and severity were recorded from six quadrats along the two diagonals of the $\mathrm{X}$ axis in the field and used to calculate average values. The prevalence of the disease was computed using the number of fields affected divided by total number of fields assessed and was expressed in percentage. The incidence of rusts was calculated by using the number of infected plants and expressed as a percentage of the total number of plants assessed for the three wheat rusts. Percentage of severity index (PSI) was calculated by following Wheelers formula (1969).

Other independent variables to be collected:

Date of planting was obtained through asking farmer, Growth stage of crop at time of assessment was recorded by using Zadoks scale, Types of variety: was obtained by asking the farmers and local development agent, Agronomic practices such as number of cultivation, frequency of weeding, fertilizer used were collected by asking farmer.

\section{Data Analysis}

Percentage data were arc sine transformed before analysis and subjected to ANOVA using SAS software (Version 9.2).The data were also analyzed by using descriptive statistical analysis over variety grown, peasant associations and districts.

\section{RESULT AND DISCUSSION}

\subsection{Distribution of Wheat Rust in Hadiya Zone}

During survey a total of 72 farmer's field were surveyed in Hadiya Zone to assess the prevalence, incidence and severity of wheat stem rust, yellow rust (stripe rust) and leaf rust. The crop growth stage during field assessment varied from 7 to 9 according to Zadok's growth scale. Relatively recently released varieties and local varieties were found in the zones and they are widely cultivated. 


\subsection{Wheat rust prevalence}

Prevalence of wheat stem rust was $100 \%$ in Misha and Duna districts but in Lemo district it was $87.5 \%$ (i.e. out of the 24 fields surveyed stem rust was found in 21 fields) (Table 1). The survey results of earlier years of Ethiopia also revealed that stem rust of wheat was commonly found in all wheat growing regions of Ethiopia (Getaneh, 1996). The most probable reasons for this might be the frequent use of local and susceptible improved cultivars in all of the surveyed areas and mono-cropping is now practicing in Ethiopia as a strategy for ease of input supply that we call cluster farming. In general, the survey result showed that the overall stem rust, yellow rust and leaf rust prevalence in the surveyed areas of Hadiya zone were $96 \%, 19.44 \%$ and $15.27 \%$ respectively (Table 1 ). In the survey area stem rust was the predominant yield limiting factor but also yellow rust (stripe rust) was also a problem as a re-emerging disease since most of the varieties grown were infected by this disease. Moreover, previously yellow rust has been a problem of highlands but now it becomes a yield limiting factor in the mind highlands. Therefore, yellow rust need research priorities following stem rust.

If susceptible improved and local cultivars continue to grow as mono-cropping system (as strategy of cluster farming) it create 'boom and burst' cycle in rust epidemics; due to thisit may not take a long time for the farmer to shift wheat production in the area to other crop. Especially, in Duna district yield loss of wheat washigh in 2016 production season due to rust epidemics as accompanied by favorable environment for rust outbreaks according to the report of district office of agriculture.

\subsection{Wheat rust incidence}

Wheat rust incidences were estimated for peasant association (PA), districts and for the entire study area (Table 1 and 2). From the total 72 fields surveyed in the district of Hadiya zone incidence of stem rust varied from $57.5 \%$ $74.17 \%$. The maximum stem rust incidence of $74.17 \%$ was recorded in Duna district followed by Misha69.87 \% (Table 1). All of the surveyed areas were categorized under high wheat stem rust incidence which was above $40 \%$ (Table 4). At PA level the highest incidence of $79.83 \%$ was recorded in both Ajerana and Heletebo in Duna district, where as the lowest incidence of $43.16 \%$ was also recorded in Jewe Lemo district.

Incidence of yellow rust and leaf rust were also surveyed in the study area and it was varied from $6.05 \%$ $3.54 \%$ and 5.3\%-3.4\% respectively (Table 1). The maximum yellow rust and leaf rust was recorded in Misha district as compared to others.In PA the maximum incidence of yellow rust $8.3 \%$ was recorded in both Debubwasgebeta and Hagedege of Misha and Duna districts respectively (Table 1 and 2). In general, disease incidence of both yellow rust and leaf rust were categorized under low incidence which was less than $20 \%$. This study showed that wheat stem rust in all the districts was the dominant followed by yellow rust. But, the incidence of rust in Hadiya zone in particular in Ethiopia in general relatively low due to the weather condition was not conducive for rust epidemics. Rain fall is commenced late and ceases early which is not unfavorable for rust epidemiology.

\subsection{Disease severity}

Over all mean stem, yellow and leaf rust severity of $9 \%, 4.44 \%$ and $4.4 \%$ respectively were recorded in Hadiya zone in the surveyed area (Table 1). The highest stem rust (12\%) and leaf rust $(3.73 \%)$ severity were recorded in Duna district, whereas the highest yellow rust (5\%) severity was recorded at Misha district. Severity of stem rust in PA varied from 4\%-17.3\% at Jewe and Haletebo respectively. In general, severity of all rusts in Hadiya zone was categorized under low class (Table 2). These may be associated with unfavorable condition for rust epidemics (like short rainy seasons as compared to the previous) and all the surveyed fields were fungicide sprayed. But still diseases like yellow rust and leaf rust needs much attention as they are becoming re-emerging. Salman et al., (2006) reported that yield losses increase proportionately with an increase in severity of the disease. According to their investigations, varieties like Morocco, WL-711, SA75, SA42 and Chakwal exhibited maximum losses of 52-57\% against the leaf rust. Moreover, diseases like bacterial stripe (Xantomona stranslucens) become a serious problem in the surveyed area and assessment and detection of viral diseases (like Barley Yellow Dwarf Virus and Cereal yellow dwarf virus) in the survey area is mandatory. Therefore, warranty is required to direct research areas in those emerging and re-emerging pathogens since they become one of the national international stark for food security. Table 1: Distribution of Stem, Leaf and Yellow rust of wheat in Hadiya Zone

\begin{tabular}{|c|c|c|c|c|c|c|c|c|c|}
\hline Districts & \multicolumn{3}{|c|}{ Stem rust } & \multicolumn{3}{|c|}{ Yellow rust } & \multicolumn{3}{|c|}{ Leaf rust } \\
\hline & $\begin{array}{c}\text { Prevalence } \\
(\%)\end{array}$ & $\begin{array}{c}\text { Incidence } \\
(\%)\end{array}$ & $\begin{array}{c}\text { Severity } \\
(\%)\end{array}$ & $\begin{array}{c}\text { Prevalence } \\
(\%)\end{array}$ & $\begin{array}{c}\text { Incidence } \\
(\%)\end{array}$ & $\begin{array}{c}\text { Severity } \\
(\%)\end{array}$ & $\begin{array}{c}\text { Prevalence } \\
(\%)\end{array}$ & $\begin{array}{c}\text { Incidence } \\
(\%)\end{array}$ & $\begin{array}{c}\text { Severity } \\
(\%)\end{array}$ \\
\hline Lemo & 87.5 & 57.5 & 5 & 16.66 & 3.54 & 1 & 12.50 & 3.40 & 1.30 \\
\hline Misha & 100 & 69.87 & 10 & 20.83 & 6.05 & 5 & 16.66 & 5.30 & 1.80 \\
\hline Duna & 100 & 74.17 & 12 & 20.83 & 3.74 & 3 & 16.66 & 4.40 & 3.73 \\
\hline Mean & 96 & 67.18 & 9 & 19.44 & 4.44 & 3 & 15.27 & 4.40 & 2.3 \\
\hline
\end{tabular}


Table 2: Wheat rust incidence and severity in the peasant associations of three districts of Hadiya zone during main cropping season of 2017

\begin{tabular}{|c|c|c|c|c|c|c|c|c|}
\hline \multirow[t]{2}{*}{ Districts } & \multirow[t]{2}{*}{ PAs } & \multirow{2}{*}{$\begin{array}{l}\text { Number of } \\
\text { fields } \\
\text { Assessed }\end{array}$} & \multicolumn{2}{|c|}{ Stem rust } & \multicolumn{2}{|c|}{ Yellow rust } & \multicolumn{2}{|c|}{ Leaf rust } \\
\hline & & & $\begin{array}{l}\text { Incidence } \\
(\%)\end{array}$ & $\begin{array}{l}\text { Severity } \\
(\%)\end{array}$ & $\begin{array}{l}\text { Incidence } \\
(\%)\end{array}$ & $\begin{array}{l}\text { Severity } \\
(\%)\end{array}$ & $\begin{array}{l}\text { Incidence } \\
(\%)\end{array}$ & $\begin{array}{l}\text { Severity } \\
(\%)\end{array}$ \\
\hline \multirow{4}{*}{ Lemo } & Jewe & 6 & 43.16 & 4.00 & 3.33 & 1.00 & 4.13 & 1.00 \\
\hline & Lambuda & 6 & 51.00 & 5.00 & 6.66 & 2.00 & 3.90 & 2.14 \\
\hline & Goratume & 6 & 68.00 & 5.00 & 0 & 0 & 0 & 0 \\
\hline & ShurmoWutibira & 6 & 67.83 & 6.00 & 4.17 & 1.00 & 4.60 & 2.03 \\
\hline \multirow{4}{*}{ Misha } & DebubWasgebeta & 6 & 68.33 & 5.60 & 8.3 & 1.67 & 6.24 & 1.33 \\
\hline & Morsito & 6 & 74.00 & 15.30 & 4.2 & 0.67 & 5.33 & 1.89 \\
\hline & Shiro & 6 & 66.33 & 5.39 & 7.5 & 1.00 & 9.78 & 2.18 \\
\hline & Gunabonotora & 6 & 70.33 & 13.70 & 4.17 & 1.67 & 0 & 0 \\
\hline \multirow{4}{*}{ Duna } & Kenkicho & 6 & 74.66 & 8.67 & 0 & 0 & 4.63 & 3.12 \\
\hline & Ajerana & 6 & 79.83 & 16.60 & 0.33 & 0.33 & 6.57 & 6.1 \\
\hline & Haletebo & 6 & 79.83 & 17.30 & 0.33 & 1.67 & 0 & 0 \\
\hline & Hagedege & 6 & 73.66 & 5.43 & 8.3 & 1.8 & 6.41 & 5.7 \\
\hline
\end{tabular}

\section{Summary and Conclusion}

Wheat rust was found to be prevalent in Hadiya zone during the main cropping seasons of 2017 and the prevalence of stem rust, yellow rust and leaf rust was $96 \%, 19.44 \%$ and $15.27 \%$ respectively.

Incidence of stem rust ranges from $57.5 \%-74.17 \%$. The maximum stem rust incidence of $74.17 \%$ was recorded in Duna district where as the lowest was recorded in Jewe, Lemo district (43.16\%). Yellow rust and leaf rust incidence in Hadiya zone were varied from $6.05 \%$ - 3.54\% and 5.3\% - 3.4\% respectively. In general, disease incidence of both yellow rust and leaf rust were categorized under low incidence which was less than $20 \%$.

Even though, the prevalence of wheat rust in Hadiya zone was high the severity was very low due to unfavorable weather condition for rust epidemics. Over all mean stem, yellow and leaf rust severity of $9 \%, 4.44 \%$ and $4.4 \%$ respectively were recorded in Hadiya zone in the surveyed area. The highest incidence and severity of stem and yellow rust were recorded from the local variety while the highest incidence and severity of leaf rust was obtained on variety Ogolcho. Since all the cultivars assessed were found to be attacked by the disease, a thorough, season based regular monitoring of the pathogen is required for the areas not covered in this survey in the main wheat growing areas of Hadiya Zone.

Countries like Ethiopia in which stem and yellow rust severely occur every year and the majority of wheat grown by subsistence farmers, for whom use of chemical fungicide against stem rust is not economical and supply of fungicides is a problem, continuous supply of resistance varieties absolutely needed to avoid wheat rust epidemics. Moreover, diseases like bacterial stripe (Xantomona stranslucens) become a serious problem in the surveyed area. In addition, assessment and detection of viral diseases (like Barley Yellow Dwarf Virus andCereal yellow dwarf virus) in the survey area is mandatory. Therefore, warranty is required to direct research areas in those emerging and re-emerging pathogens since; nowadays they become one of the national and international stark for food security.

\section{References}

Central Statistical Agency (CSA), Ministry of Finance and Economic Development Agricultural Sample Survey 2014-2015

CIMMYT (2005) Sounding the alarm on global stem rust: an assessment of race in Kenya and Ethiopia and potential for impact in neighboring countries and beyond. Mexico City, Mexico.

Dagnatchew, Y. 1967. Plant disease of economic importance in Ethiopia. Hialeslassie I University, College of Agriculture, Environmental station bulletin, Addis Ababa, Ethiopia.

Das et al., 1992).

Dereje, G. and Yaynu, H. 2000. Yield losses of crops due to disease in Ethiopia. Pest management Journal of Ethiopia. 5:55-67. http://www.eiar.gov.et/.

Getaneh Woldeab. 1996. Studies on fungal diseases of wheat at Plant Protection Research Center, 1974-1994. pp. 177-182. In: EshetuBekele, AbdurahmanAbdulahi and AynekuluYemane (eds). Proceedings of the Third Annual Conference of the Crop Protection Society of Ethiopia. May 18-19, 1995. Addis Ababa, Ethiopia.

Hailu G. 1991. Wheat production and research in Ethiopia. In Hailu Gebre-Mariam, D.G. Tanner, and Mengistu Hulluka (eds.), Wheat Research in Ethiopia: A Historical Perspective. Addis Ababa, Ethiopia: Institute of Agricultural Research and CIMMYT. Pp. 1-15. http://www.ejournalofscience.org

Haldore, H., Borlang, N.E. and Anderson, R.G. 1982. Wheat in the Third World. West View Press. Boulders, Colorado, USA.

Knott, 1989; 
Leppik, E.E. 1970. Gene centers of plants as a source of disease resisance. Annual Review of Phytopathology 8:323-344.

Mengistu, H., Getaneh, W., Yeshi, A., Rebeka, D and Ayele, B. 1991. Wheat Pathology Research in Ethiopia. In: Hailu Gebre-Mariam, Tanner, D. G., and Mengistu Hulluka. (eds.). Wheat Research in Ethiopia: A historical perspective. Addis Ababa. IAR/CIMMYT. pp. 173-217.

Park R.F., 2007. Stem rust of wheat in Australia.Australia Journal of Agricultural Research 58:558-566.

Roelfs, A.P., Singh, R.P. and Saari, E.E., 1987. Rust Diseases of Wheat: Concept and Methods of Disease Management. Mexico, D.F: CIMMYT. 81p.

Saari EE, Prescott JM (1985) A scale for appraising the foliar intensity of wheat disease. Plant Disease Reporter 59: 377-380.

Salman, A., M.A. Khan and MumtazHussain. 2006. Prediction of yield losses in wheat varieties/lines due to leaf rust in Faisalabad. Pak. J. Phytopathol., 18(2): 178-182

Singh, R.P., Huerta-Espino, J., Roelfs, A.P., 2002. The Wheat Rusts. pp.554. In: B.C. Curtis, S. Rajaram, H. Gomez Macpherson (eds.). Bread Wheat Improvement and Production. Food and Agriculture Organization (FAO) of the United Nations. Rome, Italy.

Singh, R.P., Huerta-Espino, J., Roelfs, A.P., 2002.The Wheat Rusts.In: B.C. Curtis, S. Rajaram, H. Gomez Macpherson (eds.). Bread Wheat Improvement and Production.Food and Agriculture Organization (FAO) of the United Nations. Rome, Italy. 554 p.

Stakman EC, Stewart DM, Loegering WQ (1962) Identification of physiologic races of Pucciniagraminis var. tritici.' USDA ARS, E716. United States Government Printing Office: Washington, DC.

USDA, 2015).

Zadoks, J.C. and Bouwman, J.J., 1985. Epidemiology in Europe. pp. 329-369. In: A.P. Roelfs and W.R. Bushnell (eds). The Cereal Rusts Vol. II; Diseases, Distribution, Epidemiology, and Control, Academic Press, Orlando. 